\section{O-209腰椎椎間板ヘルニア手術の排尿障害に対する 治療効果}

秋田労災

一手術までの期間と排尿障害の改並度一

福田 孝・由利康裕・富樫寿文・寺邑敏彦・藤枝信夫

土田正義

【目的】我々は腰椎椎間板ヘルニア200例について検討し， 排尿障害合併率が49.9\%であり，年䊀による発症率に差がな く，ヘルニアの手術による排尿障害の改善率が $86 \%$ と春柱 管狭窄症に比へ良好であることを報告した，しかし，急性 疾患であるへルニアの手術療法の効果に症例による差が生 じていることから，治療開始までの期間が治療効果に関係 があるものと考え検討してみた。

【対象】対象は，1991年4月～1996年3月の間に，当院整形 外科に腰椎椎間板ヘルニアで入院し, 手術前後の尿流量測 定を行った60例（男性42例：女性18例）である.

【方法】問診と尿流量測定をへルニアの術前および術後1ヶ 月後に行い, 我々の評価法に基づいて治療効果を判定し， 治療開始までの期間と治療効果について検定した.

【結果およひ考察】治療開始までの期間が短いほど治療効 果が良い結果であった。しかし，重症の椎間板ヘルニアや 過去にもへルニアの経験ある症例では, 治療効果が低い傾 向があった

【まとめ】腰椎椎間板へルニアによる排尿障害は手術によ る治療効果が期待されるが，手術までの期間が重要である ことが示唆された。

\section{0-211神経内科外来における}

\section{パーキンソン病患者の排尿障害の検討}

市立貝塚 ${ }^{1}$ 、近畿大学 ${ }^{2)}$ 、同神経内科 ${ }^{31}$

橋本 潔"、花井 禎"、井口正典"、杉山高秀 ${ }^{2}$ 、

朴 英哲 ${ }^{2}$ 、栗田 孝 ${ }^{2}$ 、高橋光雄 ${ }^{3)}$

【目的と方法】神経内科外来に通院中のパーキンソン病 患者100例の排尿障害につき検討した。

【結果と考察】100例中排尿異常を訴えたのは21例であっ た。26例に下部尿路症状の問診を行うと、中等度以上に 限っても39\%の排尿異常が認められた。排尿障害の出現 頻度と重症度(Yahr分類)の関係は、Stage 1 では5\%, Stage 2 以上では22-33\%と、Stage 2 以降はほぼ同様の出現頻 度であった。排尿障害で最も多いのは頻尿で、次いで排 尿困難、尿失禁の順であった。排尿障害の種類に性差は なかった。泌尿器科にて薬物治療を行った 6 例中 4 例で 症状の改善がみられた。膀胱内圧測定上、排尿筋反射六 進が最も多かったが、残尿のみられる症例もあり、薬物 治療に際しては、排尿筋収縮障害やDSDの関与も考慮す る必要があると思われた。

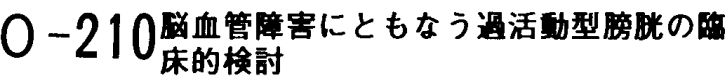

金沢大学 ${ }^{1)} \cdot$ 富山県高志リハビリテーション病院 ${ }^{2)} \cdot$ 迌立 輪島病院 ${ }^{3}$

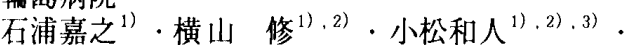

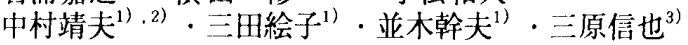

【目的】脳血管障害にともなう過活動型膀胱は臨床上よく経 験されるが、残尿をともなう症例も少なくなく、治燎に難洨 することがある。しかし、前立腺肥大症や他の神経疾患の合 併も多く、膀胱機能障害の病態は不明な点が多い。そこで、 より明確にその病態を把握するために、下部尿路通過障害を 有さない女性を対象として、その急性期、慢性期の排尿機能 につき検討した。

【対象と方法】脳血管障害を有する女性168例を対象とし、全 例に膀胱内圧測定を施行した。残尿量、膀胱谷量、発症から の日数、年齢などについて検討した。

【結果】168例中過活動型膀胱を有する症例は110例であっ た。この中で発症後 1 年未満の群と 1 年以上を経過した群 に分類すると前者の残尿率の方が後者に比べ高かった。3 年以上を経過した群でも平均残尿量は $54 \mathrm{ml}$ と比較的少な く、他の疾患の合併した症例を除外すると平均残尿量は $40 \mathrm{ml}$ と更に減少した。

【考察】器質的な下部尿路通過障害がないにも関わらず $50 \%$ 以上の残尿を有し、無抑制収縮を伴う病態はDHIC (detrusor hyperactivity with impaired contractile function)と呼ばれ慢性期の神経因性膀胱として注目され ている。しかし、下部尿路通過障害のない女性脳血管障 害症例に限定すると、排尿反射の克進が長期闑続いても 多量の残尿を有する症例は少なく、むしろそこに高齢や 糖尿病などの合併を認めてDHIC様の病態になるのではな いかと推測された。急性期に残尿の多い症例を多く経験 したが、ADLの低下に基づくものと思われた。

－212 触党センサーを利用した膀胱壁硬度の測定（セン サー測定值と組織学的変化の関係)

福島県立矤科大学 ${ }^{1} \cdot$. 福島学災病院”

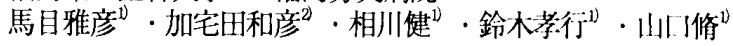

【目的】我々は、接触させただけで生体の硬さが測䇥できる センサーを開発してきた。今回はこの触賞センサーが、膀胱辟 の組織学的変化をどこまで捉えるかについて、閉塞膀胱に対し て検討した。

【方法】膀胱の硬度測定には、経尿道的測定が叮能なカテー テルタイプのセンサーを用いた。センサーの出力は、刘象の硬 己に対応した固有周波数からの偏位 (Hz) で表され、stiffnexs $(\mathrm{g} / \mathrm{cm})$ に校正した。本センサーか膀胱壁内でどの位の深さま での情報を検出できるかについて、膀胱と同じ硬さのゼラチン ダルを用いて基礎的検討を行った。閉塞膀脱は、5羽のウ壮ギ の尿道を部分閉塞した後 6 週以上のものを利用した。麻酔下で 開腹、センサーを膀胱頝部から挿入し、粘膜側から膀腅臂の硬 度を数力所ずつ測定した。また硬度測定部位をホルマリン围定 し、平滑筋と䄉維組織の占める面積を言十測した。

【結果】ゼラチンゲルを用いた検傠から、本センサーの硬度 出力值は、ゼラチン膜が溥いとその直下の硬い物質の硬度を検 出したが、 $15 \mathrm{~mm}$ 以上の厚さで完全にゼラチン自体の硬さのみ を検出した。ウサギ正常膀胱の硬度は $-378.9 \pm 101.4 \mathrm{~Hz} \quad(8.13$ $\mathrm{g} / \mathrm{cm})$ であり、組織学的には標本の全層に対し筋成分は $35.6 \%$ 、 繊維性間質成分は28.8\%であった。一方閉塞膀胱では測定した どの部位でも硬度は有意に増加し、平均 $142.4 \pm 60.5 \mathrm{~Hz}(11.98$ $\mathrm{g} / \mathrm{cm}$ ) であった。これに対応する組織学的変化は、筋成分 17.4 $\%$ 、䄉維性間質成分 $45.1 \%$ であり、筋成分の有意な減少と䋐維 成分の有意な増加を認めた。

【考案】触覚センサーは、膀胱粘膜面から少なくとも $15 \mathrm{~mm}$ 以内に起こる硬さの変化を検出できることが示惨された。動物 実験から、閉塞膀胱に伴う硬度の増加は、筋成分の減少を伴う 緘維成分の增生によることが示され、本センサーによって組織 学的変化もある程度捉えることが叮能であると推䇥される。 